\title{
MEDEDEELING OVER HET KÉBLAI DER ROTINEEZEN.
}

DOOR

C. LEKKERKERKER.

De rij- of rondedans met gezang is voor de volkeren van het Oostelijk en Zuid-Oostelijk deel van den Archipel het meest voorkomend volksvermaak. De algemeene trekken van deze volksfeesten komen, naar de beschrijvingen te oordeelen, vrijwel overeen. Ter aanvulling van de beschrijvingen dier dansfeesten bij andere volken, volgt hier eene korte beschrijving van het feest, dat ik den $29^{\text {sten }}$ Juni 1908 bijwoonde te 'Mboeain, hoofdplaats van het rijkje Oinalē, in het Westen van het eiland Rotē. De Rotineesche naam voor deze dans is Kéblai.

Het feest werd na zonsondergang ingeleid door muziek van een primitief orkest: vier gongs en een trom. Voor de gongs wordt eene lage stellage opgericht; drie gougs hangen op een rij in 't midden, de vierde aan een der schraagjes.

De trom vertoont den vorm van een zeer stompen kegel en heeft dus maar aan éne zijde een trommelvel. De trommelslager geeft de leiding en zingt er bij.

De mannen met hun fantastische pandanhoeden in honderd vormen, hoofddeksels die den vreemdeling steeds aau eene maskerade doen denken, komen langzamerhand opdagen. De vrouwen komen wat later en houden zich eerst op den achtergrond. De preliminairen voor het eigenlijke dansfeest duren wat lang. Er wordt veel en luidruchtig gelachèn en geschertst. De ouvervalschte Rotinees kan, zoodra hij in groot gezelschap is, het gillen en schreeuwen niet laten.

Het feest wordt nu ingeleid door een eleganten zwaarddans. De danser heeft het bovenlijf ontbloot, terwijl zijn heupen zijn omgord door eene der fraaie zware inheemsche selimoet's van ikatan, waarvoor Oinale bekend is. Bij zijne bewegingen, die hoe langer hoe sneller en hartstochtelijker worden, houdt hij het lichte zwaard in de rechter- en de scheede in de linkerhand. Zijn dausen wordt 
begeleid door de muziek, waarvan het rythmus hoe langer hoe leveudiger wordt.

$\mathrm{Na}$ den zwaarddanser treden twee mannen op die tandakken, begeleid door het gezang van een viertal andere mannen. Daar hunne prestaties niet wezenlijk verschillen van het tandakken op Java blijft eene nadere beschrijving achterwege.

$\mathrm{Nu}$ volgt weer een andere zwaarddaus. Waar het gevest van het zwaard overgant in het lemmer is rechthoekig op dit lemmer eene stok bevestigd, die met allerlei flodders van gekleurde lapjes en bosjes haar is versierd. Die stok wordt onder den arm gehouden bij het dausen en de versierselen zijn zoovele bewijzen van dapperheid des eigenaars. Het korte, lichte zwaard maakt eerst een wat kinderachtigen indruk. Deze indruk verlwijnt echter spoedig als de danser hartslochtelijker wordt. Duidelijk ziet men in zijne bewegingen de nabootsing van een verwoed gevecht tegen eene overmachtige menigte. Hij windt zich meer en meer op en hakt met helsch geschreeuw op den vijand los. Het is duidelijk dat bij dien man cen ingesluimerd vechtinstinkt ontwaakt is; het strijden wordt voor zijne verbeelding werkelijkheid, zijne hartstochten wordeu hem de baas. Alsof hij dit nog juist inziet staakt hij ziju spel en trekt zich afgemat terug tusschen de omstanders.

$\mathrm{Nu}$ treedt een temoekoeng (raadsheer van den radja) op, die achtereenvolgens twee verschillende $\mathrm{zwaarddansen}$ uitvoert, de laatste met het uitgetrokken zwaard, zonder schede. Bij deze danseu draagt hij als meo (voorvechter) om de enkels een band van geitenvel, met de haren er an en versierd met belletjes, zoodat bij deze dansen meer de sierlijkheid en de rythmus der bewegingen, dan het strijdvuur aan deu dag komen.

Het optreden van eene vrouw en twee kleine meisjes als solodanseressen kan stilzwijgend worden voorbij gegaan; de wijze van dansen is dezelfde als die van de talèdèk's of ronggèng's op Java; haar kleeding is minder sierlijk, maar het aantal metalen sieraden der volwassen danseres is grooter; hals, rug en armen zijn er door bedekt.

$\mathrm{Nu}$ neemt het eigenlijke Kéblai een aanvang. Vrouwen, oud en jong, en volwassen meisjes scharen zich in een kring, strekken de armen uit en laten de hand steunen op den schouder harer buren links en rechts. Aldus ontstaat een gesloten keten; de mannen bepalen zich tot de rol van toeschouwers, maar leven geheel met den dans en het gezang mee. $\mathrm{Nu}$ en dan treedt een hunner onder de armen der vrouwen door in het midden van den kring 
om eene geimproviseerde pantoen voor te dragen. Eene pantoen is het eigenlijk niet, tenminste niet altijd. Het zijn ziugend voorgedragen versregels, 1 of 2 of meer, eene toespeling bevattende op de anleiding tot het feest of op eene actualiteit voor de streek of in 't algemeen eene geestigheid inhoudende. De vrouwen nemen den regel of den slotregel als refrein over en zingen die herhaalde maleu, tot een nieuw refrein door den improvisator is anugegeven. Soms springt een tweede minstreel plotseling in den kring en wedijvert met den ander in geestigheid.

De aandacht wordt meer en meer gespanuen en er ontstaat een ware wedstrijd wie door ziju geestigheden het meest in den smaak zal vallen.

Als het aantal deelnecmsters aan den dans steeds toeneemt worden er twec kringen gevormd.

De vrouwen bewegen zich in een kring, maar zoo langzaam dat de beweging in zijdelingsche richting bijna niet is waar te nemen. Bij elk schuifelpasje naar rechts worden twee passen vóórwaarts en twee passen achterwarts gemaakt, welke passen worden geaccentueerd door een licht stampen met den rechtervoet. De ronggengs dansen mee in den kring en hebben een band met schelletjes om de enkels, door welker geklingel het lichte stampen wordt begeleid. De schuifel- en stampbewegingen worden door allen zóó volkomen gelijktịdig uitgevoerd dat oog en oor er angenaam door worden aangedaan. De bovenlijven wiegelen deinend op de mat naar links en rechts. Later op den avond gant het rustige in de bewegingen verloren. Naarmate het gezang van den improvisator en de refreinen der vrouwen wilder worden, versnellen ook de passen; bij allen komt de pret er in; de twee passen naar voren en naar achteren worden sprongen, waarbij de keten van armen zwaait en de bovenlijven sterk vóor- en achterwaarts worden gebogen; de oogen glinsteren en de borsten hijgen. Het tempo van zang en dans versuelt. $\mathrm{Bij}$ eene geestige passage van de pantoenzangers worlt de hilariteit algemeen, men klapt in de handen en nu gaan ook manneu, meegesleept door de feestrreugde, deel uitmaken van den dansenden kring en zwaaien mee. $\mathrm{Nu}$ en dan valt de muziek iu.

Het gezang der vrouwen is zeer eigenardig. In het begin, als alles nog zeer kalm gaat, antwoordt het koor alleen door een gerekt a...h ho .....h ho.... ho ..... met intervallen vau groote en kleine sekonden: f-g-f-e. Na elke passus van den voorzanger antwoordt het vrouweukoor met hetzelfde refreiu, dat als anmoediging en belooning

7• Volgr. IX. 
moet gelden. Daar de stemmen van zelf zakken zet iemand soms in hooger toonaard in, waarbij hij door de anderen wordt gevolgd. Als later de pantoens langer worden en sprekender voor het gehoor, worden de slotregels uagezongen, tot tien, twintig maal achter elkaar.

De voorzanger zingt bijv.: "Lē olē olē wanéto", welke woorden ongeveer beteekenen: "Onze heer komt hier vischvangen" welk refrein in steeds sneller tempo herhaaldelijk wordt nagezongen. De improvisator gaat dit thema verder uitwerken en wordt door het koor gevolgd. De noodige toespelingen ontbreken natuurlijk niet.

Het geheele gezang is niet on welluidend; alleen worden de stemmen van de opgewonden voorzangers spoedig heesch en rauw.

Men ziet duidelijk dat de declnemers zich uitstekend vermaken. Het feest duurt den heelen nacht door en het is een randscl hoe de deelnemers het zoo lang kunnen volhouden als het ten slotfe vrij wild en luidruchtig toegaat. Ondanks de luidruchtigheid blijft het gepast en ordelijk toegaan.

Ongeveer een zevende deel van de bevolking van Roti is tot het Christeudom overgegann; de Christenen, ofschoon wel wat minder belangstelleud voor het oude volksfeest, nemen er ook aan deel. 